\title{
Mechanism of melatonin combined with calcium carbonate on improving osteoporosis in aged rats
}

\author{
FUQIANG ZHU ${ }^{1 *}, \mathrm{ZHENDONG} \mathrm{LIU}^{2 *}$ and YUXIN REN ${ }^{1}$ \\ Departments of ${ }^{1}$ Spine Surgery and ${ }^{2}$ Orthopedics, Dezhou People's Hospital, \\ Dezhou, Shandong 253014, P.R. China
}

Received August 3, 2017; Accepted December 5, 2017

DOI: $10.3892 /$ etm.2018.6141

\begin{abstract}
The effects of melatonin and calcium carbonate on aged rats with osteoporosis (OP) were assessed. Forty female Sprague-Dawley (SD) rats aged 15 months were randomly divided into a model group (group OP), melatonin group (group $\mathrm{M}$ ), calcium carbonate group (group $\mathrm{Ca}$ ) and melatonin combined with calcium carbonate group (group $\mathrm{M}+\mathrm{Ca}$ ), while 10 rats aged 3 months were set as the control group (group NC). The changes of bone density and bone mineral level of lumbar vertebra and bilateral femur in rats of each group were observed. The levels of serum calcium, phosphorus, superoxide dismutase (SOD), malondialdehyde (MDA) and glutathione peroxidase (GSH-Px) in rats of each group were determined. Compared with those in group $\mathrm{NC}$, bone density of lumbar vertebra and bilateral femur and bone mineral level were distinctly reduced, serum calcium and activities of SOD and GSH-Px were obviously decreased, and MDA content was remarkably increased in rats of groups $\mathrm{OP}, \mathrm{M}$ and $\mathrm{Ca}$; the differences were statistically significant $(\mathrm{P}<0.05$ or $\mathrm{P}<0.01)$; compared with that in group OP, bone density of lumbar vertebra and bilateral femur and bone mineral level were remarkably increased, serum calcium and activities of SOD and GSH-Px were obviously increased, and MDA content was remarkably decreased in rats of groups $\mathrm{M}, \mathrm{Ca}$ and $\mathrm{M}+\mathrm{Ca}$; the differences were statistically significant $(\mathrm{P}<0.05$ or $\mathrm{P}<0.01)$; compared with those in groups $\mathrm{M}$ and $\mathrm{Ca}$, bone density of lumbar vertebra and bilateral femur and bone mineral level were obviously elevated, serum calcium and activities of SOD and GSH-Px were evidently elevated, and MDA content was remarkably decreased in rats of group $\mathrm{M}+\mathrm{Ca}$; the differences were statistically significant $(\mathrm{P}<0.05)$. Melatonin and calcium carbonate can significantly improve antioxidative ability in
\end{abstract}

Correspondence to: Dr Yuxin Ren, Department of Spine Surgery, Dezhou People's Hospital, 1751 Xinhu Street, Dezhou, Shandong 253014, P.R. China

E-mail: dzyy102030@163.com

${ }^{*}$ Contributed equally

Key words: osteoporosis, melatonin, calcium carbonate, bone density, oxidative stress rats with osteoporosis, increase bone density, elevate serum calcium level and reduce bone mineral loss, thus preventing and treating osteoporosis, and the combination displays more remarkable effects.

\section{Introduction}

Osteoporosis (OP) is a systemic disease characterized by the reduction of bone matrix and mineral, resulting in the destruction and rupture of trabecular bone and the increase of fragility of bone, thus reducing biomechanical properties (1). Along with increase in age, the absorption of calcium by the body decreases with the reduction of osteoblast production, which leads to the gradual increase of bone loss, finally resulting in the occurrence of OP (2). The prevention and treatment of OP include the adequate intake of vitamin D and calcium, proper exercise and other lifestyle interventions (3). Melatonin is a hormone mainly secreted by the pineal gland, which has antioxidant, scavenging free radicals, ameliorating sleep, antitumor, regulating immune response of the body and other biological functions $(4,5)$. Studies have indicated that $(6,7)$ melatonin can mediate the secretion of thyroxine and calcitonin in the body, thereby regulating calcium metabolism in vivo. In recent years, melatonin has been applied by some scholars in the prevention and treatment of OP (8). However, there is no report on melatonin combined with calcium carbonate to prevent and treat OP. Hence, by adopting melatonin combined with calcium carbonate in senile female rats, this study aimed to observe the effects of the combination on bone density, bone mineral and oxidative stress, so as to provide the basis for clinical prevention and treatment of OP.

\section{Materials and methods}

\section{Materials}

Experimental animals. Ten female specific pathogen-free (SPF) Sprague-Dawley (SD) rats aged 3 months, weighing 180-250 g, were selected. Forty female SPF SD rats aged 15 months were enrolled, which displayed osteoporosis via comparison with rats aged 3 months through determination by dual-energy X-ray absorptiometry. Fifty experimental animals were purchased from Shanghai SLAC Laboratory Animal Co., Ltd. (license no. SCXK 2012-0002; Shanghai, China). The rats were kept in cage with controlled temperature and light cycles 
( $24^{\circ} \mathrm{C}$ and $12 / 12$ light cycles) and free access to food and water. The humidity was $40 \%$. The study was approved by the Ethics Committee of Dezhou People's Hospital (Dezhou, China).

Experimental reagents. Calcium carbonate, melatonin (Sigma-Aldrich, San Francisco, CA, USA), and kits of superoxide dismutase (SOD), malondialdehyde (MDA) and glutathione peroxidase (GSH-Px) (Nanjing Jiancheng Bioengineering Institute, Nanjing, China) were prepared.

Experimental instruments. Dual-energy X-ray absorptiometry (Hologic, Marlborough, MA, USA); fully automatic biochemistry analyzer (Mindray Biomedical Electronics Co., Ltd., Shenzhen,China); continuous-wavelength multifunctional microplate reader (Tecan, Salzburg, Austria).

\section{Methods}

Grouping and medication of experimental animals. Forty senile female SPF rats were adaptively fed for one week, followed by being randomly divided into four groups with 10 animals in each group, namely model group (group OP), melatonin group (group $\mathrm{M}$ ), calcium carbonate group (group $\mathrm{Ca}$ ) and melatonin combined with calcium carbonate group (group $\mathrm{M}+\mathrm{Ca}$ ), while 10 rats aged 3 months were set as the control group (group NC). All rats were reared in an SPF system, fed with ordinary feedstuff, and ate freely during the experiment. Rats in group $M$ were treated with $40 \mathrm{mg} / \mathrm{kg}$ melatonin via intragastric administration once a day; rats in group Ca received $20 \mathrm{mg} / \mathrm{kg}$ calcium carbonate via intragastric administration once a day; rats in group $\mathrm{M}+\mathrm{Ca}$ were treated with $40 \mathrm{mg} / \mathrm{kg}$ melatonin combined with $20 \mathrm{mg} / \mathrm{kg}$ calcium carbonate via intragastric administration once a day; rats in groups NC and OP were given intragastric administration of normal saline every day for consecutive 12 weeks.

Measurement of bone density. After the end of the last intragastric administration, rats were treated with fasting for solids not liquids for $8 \mathrm{~h}$. The rats were weighed, followed by intraperitoneal injection of $50 \mathrm{mg} / \mathrm{kg} 2 \%$ pentobarbital sodium for anesthesia. The four limbs of rats were fixed, which were placed at supine position under the probe of dual energy X-ray absorptiometry; it should keep a vertical state of vertebra and horizontality of bilateral femur. The bone density of lumbar vertebras, L4-L6, and left and right femurs was measured by dual-energy X-ray absorptiometry.

Detection of serum indexes. After the measurement of bone density, the blood was extracted from abdominal aorta and centrifuged at $2,030 \mathrm{xg}$ at $4^{\circ} \mathrm{C}$ for $10 \mathrm{~min}$. The serum was separated and cryopreserved at $-80^{\circ} \mathrm{C}$. Serum calcium and phosphorus were detected by fully automatic biochemical analyzer. Serum SOD, MDA and GSH-Px were treated by sequential sample loading according to the instructions for the detection. The content of SOD in each group was measured at $550 \mathrm{~nm}$ by continuous-wavelength multifunctional enzyme analyzer. The content of MDA in each group was determined at $532 \mathrm{~nm}$, and the content of GSH-Px in each group was detected at $412 \mathrm{~nm}$.

Determination of bone mineral level. The left femur of rats was isolated, and the attached soft tissue was removed. Femur was roasted in the oven at $110^{\circ} \mathrm{C}$ for $48 \mathrm{~h}$ to the constant weight. The bone dry weight was weighed by an analytical balance, and the ratio of bone dry weight to body mass was calculated. Then, the femur was incinerated in a chamber-type electric resistance furnace at $700^{\circ} \mathrm{C}$ for $6 \mathrm{~h}$. The ash weight was weighted by an analytical balance, and the ratios of bone ash weight to body mass and bone ash weight to bone dry weight $(\%)$ were calculated.

Statistical analysis. Experimental results were expressed as mean \pm SD. The data were statistically analyzed by SPSS 20.0 software (IBM Corp., Armonk, NY, USA). The independent-samples t-test was used for comparisons between two groups, and one-way analysis of variance (ANOVA) was utilized for comparisons among multiple groups and Least Significant Difference was used for post hoc. $\mathrm{P}<0.05$ was considered to indicate a statistically significant difference.

\section{Results}

Changes of bone density of rats in each group. Compared with that in group $\mathrm{NC}$, bone density of lumbar vertebra and bilateral femur was distinctly reduced in rats of groups $\mathrm{OP}, \mathrm{M}$ and $\mathrm{Ca}$ $(\mathrm{P}<0.05$ or $\mathrm{P}<0.01)$; compared with that in group $\mathrm{OP}$, bone density of lumbar vertebra and bilateral femur was remarkably increased in rats of groups $\mathrm{M}, \mathrm{Ca}$ and $\mathrm{M}+\mathrm{Ca}(\mathrm{P}<0.05)$; compared with that in groups $\mathrm{M}$ and $\mathrm{Ca}$, bone density of lumbar vertebra and bilateral femur was obviously elevated in rats of group $\mathrm{M}+\mathrm{Ca}(\mathrm{P}<0.05)$; there was no significant difference in comparison of bone density between groups $\mathrm{M}+\mathrm{Ca}$ and $\mathrm{NC}$ $(\mathrm{P}>0.05)$. The results indicated that melatonin and calcium carbonate could significantly ameliorate bone density in rats with osteoporosis, and the combination displayed more remarkable effects (Table I).

Bone mineral metabolism in rats of each group. Compared with those in group $\mathrm{NC}$, bone dry weight, the ratio of bone dry weight to body mass, bone ash weight and the ratios of bone ash weight to body mass and bone ash weight to bone dry weight of rats in groups OP, M and Ca were significantly reduced $(\mathrm{P}<0.05$ or $\mathrm{P}<0.01)$; compared with those in group $\mathrm{OP}$, these indexes of rats in groups $\mathrm{M}, \mathrm{Ca}$ and $\mathrm{M}+\mathrm{Ca}$ were obviously increased $(\mathrm{P}<0.05$ or $\mathrm{P}<0.01)$; compared with those in groups $\mathrm{M}$ and $\mathrm{Ca}$, these indexes of rats in group $\mathrm{M}+\mathrm{Ca}$ were remarkably elevated $(\mathrm{P}<0.05)$; the comparisons in these indexes between groups $\mathrm{M}+\mathrm{Ca}$ and $\mathrm{NC}$ had no distinct differences $(\mathrm{P}>0.05)$. The results revealed that melatonin and calcium carbonate could significantly reduce bone mineral loss in rats with osteoporosis, and the combination displayed more remarkable effects (Tables II and III).

Changes of serum calcium and phosphorus levels in rats of each group. Compared with that in group NC, serum calcium level was significantly reduced in rats of groups $\mathrm{OP}, \mathrm{M}$ and $\mathrm{Ca}$ $(\mathrm{P}<0.05$ or $\mathrm{P}<0.01)$; compared with that in group $\mathrm{OP}$, serum calcium level was obviously increased in rats of groups $\mathrm{M}$, $\mathrm{Ca}$ and $\mathrm{M}+\mathrm{Ca}(\mathrm{P}<0.05)$; compared with that in groups $\mathrm{M}$ and $\mathrm{Ca}$, serum calcium level was remarkably elevated in rats of group $\mathrm{M}+\mathrm{Ca}(\mathrm{P}<0.05)$; the comparison in this level between groups $\mathrm{M}+\mathrm{Ca}$ and $\mathrm{NC}$ had no distinct difference $(\mathrm{P}>0.05)$. There was no evident difference in comparison of serum phosphorus level in rats among groups $(\mathrm{P}>0.05)$. The results revealed that melatonin and calcium carbonate could significantly increase serum calcium level in rats with 
Table I. Comparisons of bone density of lumbar vertebra and bilateral femur in rats among groups.

\begin{tabular}{lllll}
\hline Groups & No. & Lumbar vertebra & Left femur & Right femur \\
\hline NC & 10 & $0.252 \pm 0.014$ & $0.248 \pm 0.017$ & $0.249 \pm 0.017$ \\
OP & 10 & $0.177 \pm 0.021^{\mathrm{b}}$ & $0.172 \pm 0.016^{\mathrm{b}}$ & $0.174 \pm 0.018^{\mathrm{b}}$ \\
$\mathrm{M}$ & 10 & $0.210 \pm 0.018^{\mathrm{a}, \mathrm{c}}$ & $0.212 \pm 0.021^{\mathrm{a}, \mathrm{c}}$ & $0.215 \pm 0.015^{\mathrm{a}, \mathrm{c}}$ \\
$\mathrm{Ca}$ & 10 & $0.221 \pm 0.018^{\mathrm{a}, \mathrm{c}}$ & $0.219 \pm 0.016^{\mathrm{a}, \mathrm{c}}$ & $0.220 \pm 0.022^{\mathrm{a}, \mathrm{c}}$ \\
$\mathrm{M}+\mathrm{Ca}$ & 10 & $0.248 \pm 0.020^{\mathrm{d}-\mathrm{f}}$ & $0.243 \pm 0.018^{\mathrm{d}-\mathrm{f}}$ & $0.245 \pm 0.019^{\mathrm{d}-\mathrm{f}}$ \\
\hline
\end{tabular}

Compared with group $\mathrm{NC}$, ${ }^{\mathrm{a}} \mathrm{P}<0.05$ and ${ }^{\mathrm{b}} \mathrm{P}<0.01$; compared with group $\mathrm{OP},{ }^{\mathrm{c}} \mathrm{P}<0.05$ and ${ }^{\mathrm{d}} \mathrm{P}<0.01$; compared with group $\mathrm{M}$, ${ }^{\mathrm{e}} \mathrm{P}<0.05$; compared with group $\mathrm{Ca},{ }^{\mathrm{f}} \mathrm{P}<0.05$.

Table II. Comparisons of bone dry weight in rats among groups.

\begin{tabular}{lcccc}
\hline Groups & No. & Body mass $(\mathrm{g})$ & Bone dry weight $(\mathrm{mg})$ & Bone dry weight/body mass $(\mathrm{g} / \mathrm{kg})$ \\
\hline $\mathrm{NC}$ & 10 & $332.35 \pm 18.71$ & $580.16 \pm 23.68$ & $1.75 \pm 0.09$ \\
$\mathrm{OP}$ & 10 & $328.91 \pm 17.22$ & $497.47 \pm 25.10^{\mathrm{b}}$ & $1.51 \pm 0.06^{\mathrm{b}}$ \\
$\mathrm{M}$ & 10 & $330.64 \pm 12.16$ & $532.04 \pm 27.82^{\mathrm{a}, \mathrm{c}}$ & $1.61 \pm 0.09^{\mathrm{a}, \mathrm{c}}$ \\
$\mathrm{Ca}$ & 10 & $334.11 \pm 14.40$ & $538.48 \pm 20.98^{\mathrm{a}, \mathrm{c}}$ & $1.62 \pm 0.10^{\mathrm{a}, \mathrm{c}}$ \\
$\mathrm{M}+\mathrm{Ca}$ & 10 & $331.52 \pm 17.84$ & $571.60 \pm 22.73^{\mathrm{d}-\mathrm{f}}$ & $1.72 \pm 0.13^{\mathrm{c}-\mathrm{f}}$ \\
\hline
\end{tabular}

Compared with group $\mathrm{NC}$, ${ }^{\mathrm{a}} \mathrm{P}<0.05$ and ${ }^{\mathrm{b}} \mathrm{P}<0.01$; compared with group $\mathrm{OP},{ }^{\mathrm{c}} \mathrm{P}<0.05$ and ${ }^{\mathrm{d}} \mathrm{P}<0.01$; compared with group $\mathrm{M}$, ${ }^{\mathrm{e}} \mathrm{P}<0.05$; compared with group $\mathrm{Ca},{ }^{\mathrm{f}} \mathrm{P}<0.05$.

Table III. Comparisons of bone ash weight in rats among groups.

\begin{tabular}{lccccc}
\hline Groups & No. & $\begin{array}{c}\text { Body mass } \\
(\mathrm{g})\end{array}$ & $\begin{array}{c}\text { Bone ash weight } \\
(\mathrm{mg})\end{array}$ & $\begin{array}{c}\text { Bone ash weight/ } \\
\text { body mass }(\mathrm{g} / \mathrm{kg})\end{array}$ & $\begin{array}{c}\text { Bone ash weight/ } \\
\text { bone dry weight }(\%)\end{array}$ \\
\hline $\mathrm{NC}$ & 10 & $332.35 \pm 18.71$ & $382.87 \pm 20.09$ & $1.15 \pm 0.06$ & $65.99 \pm 1.13$ \\
OP & 10 & $328.91 \pm 17.22$ & $290.04 \pm 18.53^{\mathrm{b}}$ & $0.88 \pm 0.08^{\mathrm{b}}$ & $58.30 \pm 0.94^{\mathrm{b}}$ \\
$\mathrm{M}$ & 10 & $330.64 \pm 12.16$ & $331.61 \pm 16.78^{\mathrm{b}, \mathrm{c}}$ & $1.00 \pm 0.05^{\mathrm{a}, \mathrm{c}}$ & $62.33 \pm 0.81^{\mathrm{a}, \mathrm{c}}$ \\
$\mathrm{Ca}$ & 10 & $334.11 \pm 14.40$ & $335.29 \pm 19.24^{\mathrm{a}, \mathrm{c}}$ & $1.01 \pm 0.05^{\mathrm{a}, \mathrm{c}}$ & $62.27 \pm 0.90^{\mathrm{a}, \mathrm{c}}$ \\
$\mathrm{M}+\mathrm{Ca}$ & 10 & $331.52 \pm 17.84$ & $374.83 \pm 18.33^{\mathrm{d}-\mathrm{f}}$ & $1.13 \pm 0.04^{\mathrm{d}-\mathrm{f}}$ & $65.58 \pm 0.77^{\mathrm{d}-\mathrm{f}}$ \\
\hline
\end{tabular}

Compared with group $\mathrm{NC}$, ${ }^{\mathrm{a}} \mathrm{P}<0.05$ and ${ }^{\mathrm{b}} \mathrm{P}<0.01$; compared with group $\mathrm{OP},{ }^{\mathrm{c}} \mathrm{P}<0.05$ and ${ }^{\mathrm{d}} \mathrm{P}<0.01$; compared with group $\mathrm{M}$, ${ }^{\mathrm{e}}<0.05$; compared with group $\mathrm{Ca},{ }^{\mathrm{f}} \mathrm{P}<0.05$.

osteoporosis, and the combination displayed more remarkable effects (Table IV).

Changes of serum SOD, GSH-Px activity and MDA content in rats of each group. Compared with those in group $\mathrm{NC}$, serum SOD and GSH-Px activities in rats of groups OP, $\mathrm{M}$ and Ca were significantly reduced $(\mathrm{P}<0.05$ or $\mathrm{P}<0.01)$, and MDA content was obviously increased $(\mathrm{P}<0.05$ or $\mathrm{P}<0.01)$; compared with those in group OP, serum SOD and GSH-Px activities in rats of groups $\mathrm{M}, \mathrm{Ca}$ and $\mathrm{M}+\mathrm{Ca}$ were obviously increased $(\mathrm{P}<0.05$ or $\mathrm{P}<0.01)$, and MDA content was obviously decreased $(\mathrm{P}<0.05$ or $\mathrm{P}<0.01)$; compared with those in groups $\mathrm{M}$ and $\mathrm{Ca}$, serum SOD and GSH-Px activities in rats of group $\mathrm{M}+\mathrm{Ca}$ were remarkably elevated $(\mathrm{P}<0.05)$, and MDA content was distinctly reduced $(\mathrm{P}<0.05)$; the comparison in these levels between
Table IV. Comparisons of calcium and phosphorus levels in rats among groups.

\begin{tabular}{lclc}
\hline Groups & No. & $\begin{array}{c}\text { Calcium } \\
(\mathrm{mmol} / \mathrm{l})\end{array}$ & $\begin{array}{c}\text { Phosphorus } \\
(\mathrm{mmol} / \mathrm{l})\end{array}$ \\
\hline $\mathrm{NC}$ & 10 & $2.68 \pm 0.15$ & $1.55 \pm 0.13$ \\
$\mathrm{OP}$ & 10 & $1.93 \pm 0.20^{\mathrm{b}}$ & $1.52 \pm 0.17$ \\
$\mathrm{M}$ & 10 & $2.27 \pm 0.18^{\mathrm{a}, \mathrm{c}}$ & $1.56 \pm 0.21$ \\
$\mathrm{Ca}$ & 10 & $2.36 \pm 0.21^{\mathrm{a}, \mathrm{d}}$ & $1.53 \pm 0.19$ \\
$\mathrm{M}+\mathrm{Ca}$ & 10 & $2.59 \pm 0.17^{\mathrm{d}-\mathrm{f}}$ & $1.55 \pm 0.17$
\end{tabular}

Compared with group $\mathrm{NC},{ }^{\mathrm{a}} \mathrm{P}<0.05$ and ${ }^{\mathrm{b}} \mathrm{P}<0.01$; compared with group $\mathrm{OP},{ }^{\mathrm{c}} \mathrm{P}<0.05$ and ${ }^{\mathrm{d}} \mathrm{P}<0.01$; compared with group $\mathrm{M},{ }^{\mathrm{e}} \mathrm{P}<0.05$; compared with group $\mathrm{Ca},{ }^{\mathrm{P}}<0.05$. 


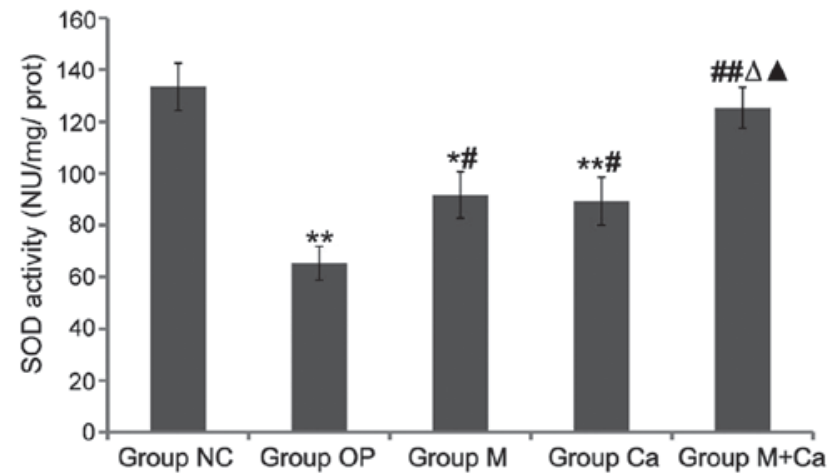

Figure 1. Comparison of superoxide dismutase (SOD) activity among groups. Compared with group NC, ${ }^{*} \mathrm{P}<0.05$ and ${ }^{* *} \mathrm{P}<0.01$; compared with group OP, ${ }^{\#} \mathrm{P}<0.05$ and ${ }^{\# \#} \mathrm{P}<0.01$; compared with group $\mathrm{M},{ }^{\triangle} \mathrm{P}<0.05$; compared with group $\mathrm{Ca},{ }^{\wedge} \mathrm{P}<0.05$.

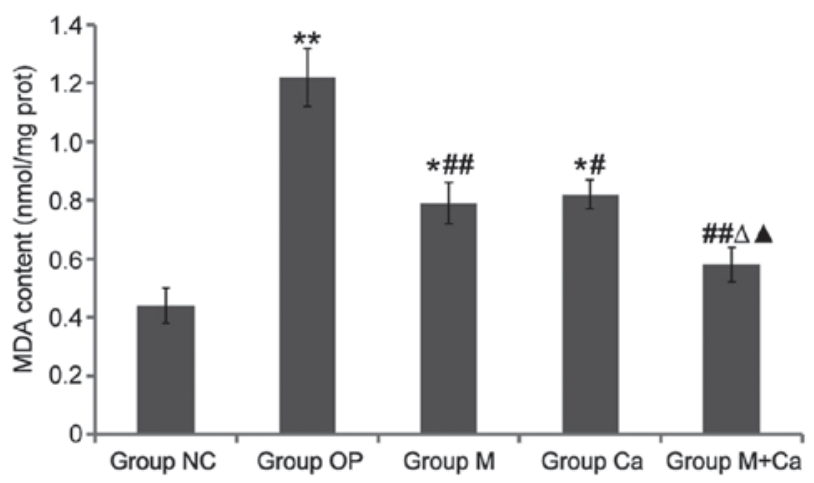

Figure 2. Comparison of malondialdehyde (MDA) content among groups. Compared with group NC, ${ }^{*} \mathrm{P}<0.05$ and ${ }^{* *} \mathrm{P}<0.01$; compared with group OP, ${ }^{\#} \mathrm{P}<0.05$ and ${ }^{\# \prime} \mathrm{P}<0.01$; compared with group $\mathrm{M},{ }^{\triangle} \mathrm{P}<0.05$; compared with group $\mathrm{Ca},{ }^{\wedge} \mathrm{P}<0.05$.

groups $\mathrm{M}+\mathrm{Ca}$ and $\mathrm{NC}$ had no distinct differences $(\mathrm{P}>0.05)$. The results revealed that melatonin and calcium carbonate could significantly increase serum SOD and GSH-Px activities and reduce MDA content, and the combination displayed more remarkable effects (Figs. 1-3).

\section{Discussion}

OP is mainly characterized by degenerative changes of bone tissue microstructure, osteopenia and increased bone fragility thus remarkably increasing fracture risk (9). OP is prevalent in elderly people, and age is a major risk factor of OP $(10,11)$. In recent years, as China entered the time of the aged, the incidence of OP has increased year by year, and its fracture and other complications seriously affect people's lives. The study on OP has attracted wide attention of scholars in China and elesewhere. Calcium is one of the important trace elements in minerals of the body, and the main pathological change of OP is bone mineral loss (12). Therein, calcium deficiency is an important cause of OP (2). Thus, calcium supplementation is the most effective and safe method in the prevention and treatment of OP (13). Appropriate supplementation of calcium can enhance bone calcium levels and increase bone density, thereby significantly ameliorating bone formation (14). Adequate intake of calcium and vitamin D can prevent bone loss in

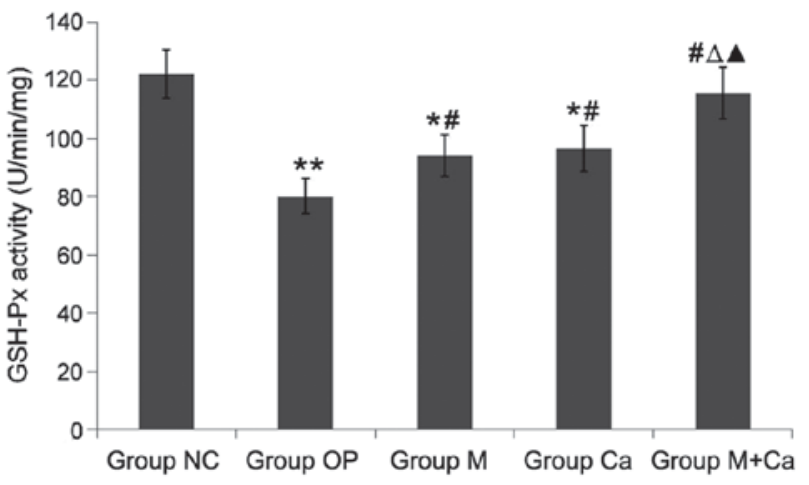

Figure 3. Comparison of glutathione peroxidase (GSH-Px) activity among groups. Compared with group $\mathrm{NC},{ }^{*} \mathrm{P}<0.05 ;{ }^{* *} \mathrm{P}<0.01$; compared with group $\mathrm{OP},{ }^{\#} \mathrm{P}<0.05$; compared with group $\mathrm{M},{ }^{\wedge} \mathrm{P}<0.05$; compared with group $\mathrm{Ca},{ }^{\wedge} \mathrm{P}<0.05$.

postmenopausal women, and is able to maintain bone density of femoral neck and lumbar vertebras (15), thus reducing the incidence of fractures (16). The measurement of serum calcium and phosphorus can indirectly reflect bone metabolism in the body (17). This study revealed severely decreased bone density, bone mineral loss and reduced serum calcium level in elderly OP rats. The supplement of exogenous calcium carbonate can significantly increase bone density, elevate serum calcium level and reduce bone mineral loss in OP rats.

Melatonin is an indole hormone mainly secreted by pineal gland; the secretion is rhythmic, which is regulated by photoperiod and suprachiasmatic nucleus (18). The synthesis and secretion of melatonin is increased in the dark, and the amount of secretion at night is 5-10 times than that of in the daytime (19). When an organism enters old age, the circadian rhythm of melatonin gradually becomes gentle and even disappears (20). Melatonin has a wide range of biological functions, and its mechanisms are different (21). In terms of bone metabolism, melatonin can inhibit the proliferation and differentiation of osteoclasts, advance the proliferation and differentiation of osteoblasts and promote the mineralization of bone matrix through a variety of signaling pathways $(22,23)$. Cell experiments have shown that melatonin can stimulate the proliferation of bone cells and osteoblasts in a dose-dependent manner (24). Moreover, it can upregulate the expression of runt-related transcription factor 2 (RUNX2) and inhibit the expression of peroxisome proliferator-activated receptor (PPAR- $\gamma$ ), thus promoting the differentiation of bone marrow mesenchymal stem cells into osteoblasts (25). Animal experiments revealed that melatonin can significantly increase bone density and trabecular bone volume in male mice, but distinctly reduce the size and number of osteoclasts (26). This study indicated that supplement of exogenous melatonin can significantly increase the bone density in OP rats, elevate serum calcium level and reduce bone mineral loss, which has a synergistic effect with calcium carbonate, and the combination displayed more remarkable effects.

The bone toxicity caused by reactive oxygen species plays an important role in the occurrence of OP (27). Excessive bone absorption in the organism increases the production of reactive oxygen species, which leads to the destruction of osteoclasts and osteoblasts, resulting in the reduction of bone 
mass. With the increase of age, the level of free radicals in the body is gradually increased, while smoking, drinking and other unhealthy lifestyles can induce oxidative stress and elevate the level of free radicals, thus increasing bone absorption (28). Animal experiments revealed that the level of antioxidant stress in the body decreases with the reduction of melatonin levels. It can be seen that maintaining normal melatonin levels can reduce the damage of free radicals (29). This study indicated that melatonin and calcium carbonate can increase the activities of SOD and GSH-Px and reduce the production of MDA in OP rats, thereby exerting the effect of antioxidative stress; they have a synergistic effect, and the combination displayed more remarkable effects.

In conclusion, the study reveals severely decreased bone density, bone mineral loss, reduced serum calcium level and oxidative stress in OP rats, but the supplement of exogenous melatonin and calcium carbonate can significantly improve antioxidative stress ability, increase bone density, elevate serum calcium level and reduce bone mineral loss, thus preventing and treating osteoporosis. These two substances have a synergistic effect, and the combination displays more remarkable effects, which provides an experimental basis for the clinical prevention and treatment of osteoporosis. The related molecular biological mechanisms need to be further investigated.

\section{Competing interests}

The authors declare that they have no competing interests.

\section{References}

1. Raisz LG: Pathogenesis of osteoporosis: concepts, conflicts, and prospects. J Clin Invest 115: 3318-3325, 2005.

2. Reid IR, Ames RW, Evans MC, Gamble GD and Sharpe SJ: Effect of calcium supplementation on bone loss in postmenopausal women. N Engl J Med 328: 460-464, 1993.

3. Shin S and Joung H: A dairy and fruit dietary pattern is associated with a reduced likelihood of osteoporosis in Korean postmenopausal women. Br J Nutr 110: 1926-1933, 2013.

4. Zawawi MS, Dharmapatni AA, Cantley MD, McHugh KP, Haynes DR and Crotti TN: Regulation of ITAM adaptor molecules and their receptors by inhibition of calcineurin-NFAT signalling during late stage osteoclast differentiation. Biochem Biophys Res Commun 427: 404-409, 2012.

5. Macchi MM and Bruce JN: Human pineal physiology and functional significance of melatonin. Front Neuroendocrinol 25: 177-195, 2004.

6. Csaba G and Baráth P: The effect of pinealectomy on the parafollicular cells of the rat thyroid gland. Acta Anat (Basel) 88: 137-146, 1974

7. Csaba G and Bókay J: The effect of melatonin and corpus pineale extract on serum electrolytes in the rat. Acta Biol Acad Sci Hung 28: 143-144, 1977.

8. Witt-Enderby PA, Radio NM, Doctor JS and Davis VL: Therapeutic treatments potentially mediated by melatonin receptors: Potential clinical uses in the prevention of osteoporosis, cancer and as an adjuvant therapy. J Pineal Res 41: 297-305, 2006.

9. Mundy G, Garrett R, Harris S, Chan J, Chen D, Rossini G, Boyce B, Zhao M and Gutierrez G: Stimulation of bone formation in vitro and in rodents by statins. Science 286: 1946-1949, 1999.

10. Barrios C, Broström LA, Stark A and Walheim G: Healing complications after internal fixation of trochanteric hip fractures: The prognostic value of osteoporosis. J Orthop Trauma 7: 438-442, 1993

11. Kim WY, Han CH, Park JI and Kim JY: Failure of intertrochanteric fracture fixation with a dynamic hip screw in relation to pre-operative fracture stability and osteoporosis. Int Orthop 25: 360-362, 2001
12. Bidwell JP, Alvarez MB, Hood M Jr and Childress P: Functional impairment of bone formation in the pathogenesis of osteoporosis: The bone marrow regenerative competence. Curr Osteoporos Rep 11: 117-125, 2013.

13. Shuid AN, Mohamad S, Mohamed N, Fadzilah FM, Mokhtar SA, Abdullah S, Othman F, Suhaimi F, Muhammad N and Soelaiman IN: Effects of calcium supplements on fracture healing in a rat osteoporotic model. J Orthop Res 28: 1651-1656, 2010.

14. Orwoll ES, McClung MR, Oviatt SK, Recker RR and Weigel RM: Histomorphometric effects of calcium or calcium plus 25-hydroxyvitamin D3 therapy in senile osteoporosis. J Bone Miner Res 4: 81-88, 1989.

15. Cooper L, Clifton-Bligh PB, Nery ML, Figtree G, Twigg S, Hibbert E and Robinson BG: Vitamin D supplementation and bone mineral density in early postmenopausal women. Am J Clin Nutr 77: 1324-1329, 2003.

16. Chapuy MC, Arlot ME, Delmas PD and Meunier PJ: Effect of calcium and cholecalciferol treatment for three years on hip fractures in elderly women. BMJ 308: 1081-1082, 1994.

17. Botolin S, Faugere MC, Malluche H, Orth M, Meyer R and McCabe LR: Increased bone adiposity and peroxisomal proliferator-activated receptor-gamma2 expression in type I diabetic mice. Endocrinology 146: 3622-3631, 2005.

18. Zawilska JB, Skene DJ and Arendt J: Physiology and pharmacology of melatonin in relation to biological rhythms. Pharmacol Rep 61: 383-410, 2009.

19. Zeitzer JM, Duffy JF, Lockley SW, Dijk DJ and Czeisler CA: Plasma melatonin rhythms in young and older humans during sleep, sleep deprivation, and wake. Sleep 30: 1437-1443, 2007.

20. Toffol E, Kalleinen N, Haukka J, Vakkuri O, Partonen T and Polo-Kantola P: Melatonin in perimenopausal and postmenopausal women: Associations with mood, sleep, climacteric symptoms, and quality of life. Menopause 21: 493-500, 2014.

21. Liu J, Huang F and He HW: Melatonin effects on hard tissues: Bone and tooth. Int J Mol Sci 14: 10063-10074, 2013.

22. Halıcı M, Öner M, Güney A, Canöz Ö, Narin F and Halıcı C: Melatonin promotes fracture healing in the rat model. Eklem Hastalik Cerrahisi 21: 172-177, 2010.

23. Satomura K, Tobiume S, Tokuyama R, Yamasaki Y, Kudoh K, Maeda E and Nagayama M: Melatonin at pharmacological doses enhances human osteoblastic differentiation in vitro and promotes mouse cortical bone formation in vivo. J Pineal Res 42: 231-239, 2007.

24. Nakade O, Koyama H, Ariji H, Yajima A and Kaku T: Melatonin stimulates proliferation and type I collagen synthesis in human bone cells in vitro. J Pineal Res 27: 106-110, 1999.

25. Zhang L, Su P, Xu C, Chen C, Liang A, Du K, Peng Y and Huang D: Melatonin inhibits adipogenesis and enhances osteogenesis of human mesenchymal stem cells by suppressing PPAR $\gamma$ expression and enhancing Runx2 expression. J Pineal Res 49: 364-372, 2010.

26. Koyama H, Nakade O, Takada Y, Kaku T and Lau KH: Melatonin at pharmacologic doses increases bone mass by suppressing resorption through down-regulation of the RANKL-mediated osteoclast formation and activation. J Bone Miner Res 17: 1219-1229, 2002

27. Park BG, Yoo CI, Kim HT, Kwon CH and Kim YK: Role of mitogen-activated protein kinases in hydrogen peroxide-induced cell death in osteoblastic cells. Toxicology 215: 115-125, 2005.

28. Lee NK, Choi YG, Baik JY, Han SY, Jeong DW, Bae YS, Kim N and Lee SY: A crucial role for reactive oxygen species in RANKLinduced osteoclast differentiation. Blood 106: 852-859, 2005.

29. Galano A, Tan DX and Reiter RJ: Melatonin as a natural ally against oxidative stress: A physicochemical examination. J Pineal Res 51: 1-16, 2011.

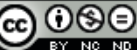

This work is licensed under a Creative Commons Attribution-NonCommercial-NoDerivatives 4.0 International (CC BY-NC-ND 4.0) License. 